\title{
Nematode Management in Cole Crops ${ }^{1}$
}

\author{
Z. J. Grabau and J. W. Noling 2
}

Plant-parasitic nematodes are small microscopic roundworms that live in the soil and attack the roots of plants. Crop production problems induced by nematodes therefore generally occur as a result of root dysfunction; nematodes reduce rooting volume and the efficiency with which roots forage for and use water and nutrients. Many different genera and species of nematodes can be important to crop production in Florida. In many cases a mixed community of plant-parasitic nematodes is present in a field, rather than having a single species occurring alone. Root-knot, sting, stubby-root, and awl nematodes are important pests of crucifers; a cyst nematode is serious in local areas of central Florida. Radishes are occasionally deformed slightly by root-knot nematodes, but they normally escape serious injury because of their short growth period (less than a complete nematode life cycle). The host range of these nematodes, as with others, includes many different weeds and most if not all of the commercially grown vegetables within the state. Yield reductions can be extensive but vary significantly between plant and nematode species. In addition to the direct crop damage caused by nematodes, many of these species have also been shown to predispose plants to infection by fungal or bacterial pathogens or to transmit virus diseases, which contribute to additional yield reductions. A key to nematode management for many of these crops is the use of pest-free transplants, which should be produced in sterile growing medium or soil fumigated with a multipurpose fumigant.

\section{Plant-Parasitic Nematodes}

Plant-parasitic nematodes are microscopic roundworms that feed on plant tissue. Most plant-parasitic nematodes live in the soil and attack the roots of plants. This can reduce yield by reducing root function and consequently plant growth. Cole crops are selected plants in the family Brassicaceae whose leaves or shoots are harvested. They include cabbage, broccoli, Brussels sprouts, cauliflower, collards, and others. Many different genera and species of nematodes cause damage in Florida cole crop production (Rhoades 1986; McSorley and Dickson 1995; Perez et al. 2000b). In many cases, a mixed community of plantparasitic nematodes is present in a field, rather than a single species. The most important nematode pests of cole crops in Florida are species of root-knot nematodes (Meloidogyne spp.), sting nematode (Belonolaimus longicaudatus), stubby-root nematodes (primarily Nanidorus minor), and awl nematode (Dolichorus spp.). For more information about these nematodes, see the following publications on sting nematode (Crow 2018), stubby-root nematodes (Crow 2017), and awl nematode (Crow and Brammer 2018). Sugarbeet cyst nematode (Heterodera schachtii) has been a serious problem in local areas of central Florida (Rhoades 1970). Several other nematodes are associated with cole crops, but their impact on yield is either low or unknown.

Plant-parasitic nematodes can be grouped based on their feeding habits, and this can be an important factor in diagnostics and management. Nematode life stages include the egg, four pre-adult juvenile stages, and a mature adult

1. This document is ENY-024, one of a series of the Department of Entomology and Nematology, UF/IFAS Extension. Original publication date March 1999. Revised December 2016 and November 2020. Visit the EDIS website at http://edis.ifas.ufl.edu.

2. Z. J. Grabau, assistant professor, Entomology and Nematology Department; J. W. Noling, professor emeritus, Entomology and Nematology Department; UF/IFAS Citrus Research and Education Center; UF/IFAS Extension, Gainesville, FL 32611.

The Institute of Food and Agricultural Sciences (IFAS) is an Equal Opportunity Institution authorized to provide research, educational information and other services

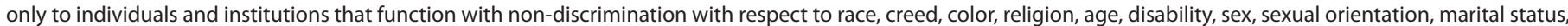

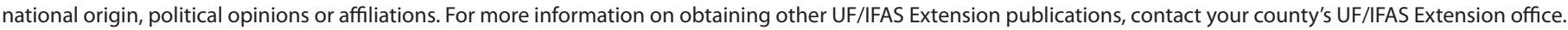
U.S. Department of Agriculture, UF/IFAS Extension Service, University of Florida, IFAS, Florida A \& M University Cooperative Extension Program, and Boards of County Commissioners Cooperating. Nick T. Place, dean for UF/IFAS Extension. 
stage. All plant-parasitic nematodes have a stylet, which is a needle-like mouthpart that is typically hollow and used to draw nutrients from the host plant. Migratory ectoparasites (Figure 1) are mobile (migratory), and only their stylet enters the root while feeding; the rest of the body remains outside (ectoparasite). These nematodes move from one root feeding site to another. Sting, stubbyroot, and awl nematodes are migratory ectoparasites.

Migratory endoparasites are mobile and move from site to site when feeding, but fully enter the root to feed. Lesion nematode (Pratylenchus spp.) is an example of a migratory ectoparasite (Figure 2). Sedentary endoparasites enter the root to feed, but they induce the plant to form a complex feeding site and do not move from this site once established as a juvenile or adult female (Figure 3 ). The female stage of sedentary endoparasites becomes enlarged as it feeds and produces hundreds of eggs. Root-knot and cyst nematodes are sedentary endoparasites.

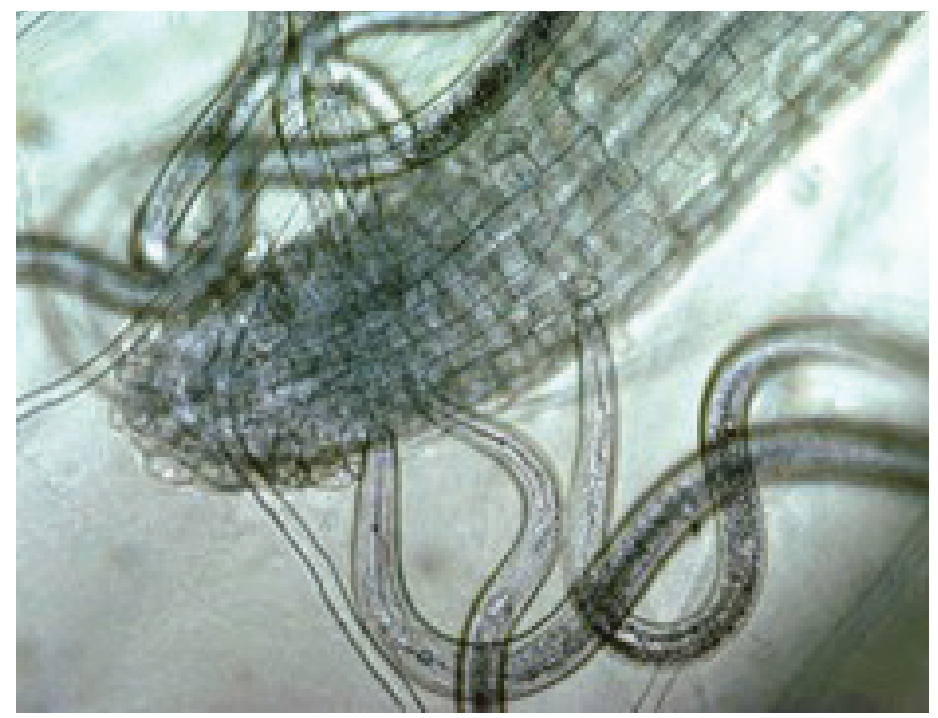

Figure 1. Migratory ectoparasites (sting nematode pictured here) insert their stylets to feed, leaving their bodies outside the root. Credits: Ole Becker, University of California Riverside. Used with permission

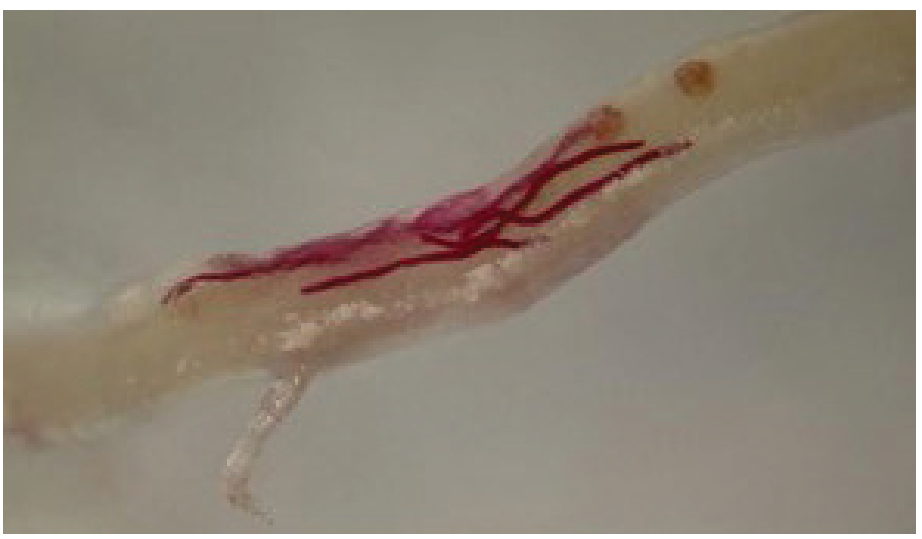

Figure 2. Migratory endoparasites feed with their bodies inside the root and move from site to site in the root to feed. Generally, all life stages are of a relatively similar size.

Credits: A. C. Hixson, UF/IFAS

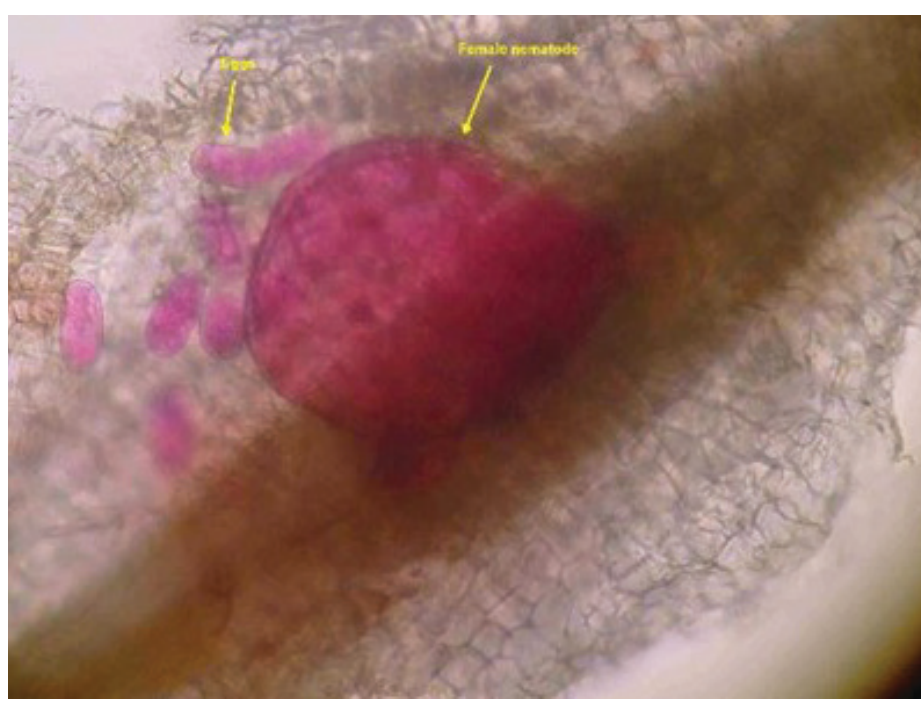

Figure 3. Sedentary endoparasites (root-knot nematode pictured here) establish a complex feeding site in the root as a juvenile or immature female and do not move from that site for the rest of their lives. Adult females enlarge as they feed and produce eggs.

Credits: N. S. Sekora, UF/IFAS

\section{Symptoms and Damage}

Monitor for symptoms to spot potential nematode problems. Subsequent confirmation by sampling, as described in the next section, is generally necessary because foliar symptoms of nematode damage can be indistinct, and yield loss may occur when there are few to no symptoms. Typical symptoms of nematode injury can involve both aboveground and belowground plant parts. Foliar symptoms of nematode infestation of roots generally involve stunting, premature wilting and slow recovery to improved soil moisture conditions, leaf chlorosis (yellowing), and other symptoms characteristic of nutrient deficiency (Figure 4). In severe cases, plant parts may die and turn brown (necrosis), or entire plants may die, resulting in reduced stand (Figure 5). These severe foliar symptoms, particularly early in the year, are typical of sting nematode infestation (Figure 6). In contrast, root-knot nematode symptoms may be more subtle early in the growing season (wilting, chlorosis), with severe symptoms (stunting, necrosis) manifesting later in the growing season (Figure 7). Plants exhibiting stunt or decline symptoms usually occur in patches of nonuniform growth rather than evenly throughout a field and correspond to varying nematode abundances and environmental conditions (soil type, moisture, fertility). Stubby-root nematodes transmit tobacco rattle virus, a strain of which is known to affect the cole crop spinach in some regions of the United States (Kurppa et al. 1981). The most distinct symptoms of this virus on spinach are bright yellow blotches and spots, but necrosis and generalized chlorosis may also occur. 


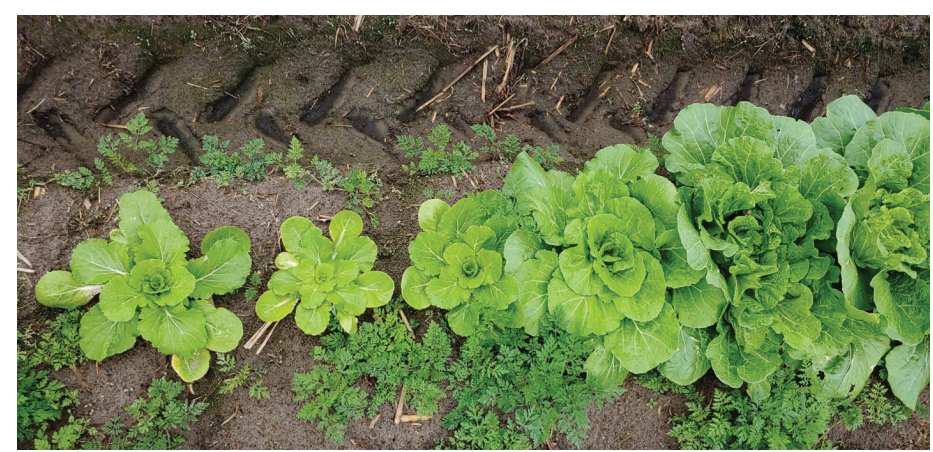

Figure 4. Stunting and mild chlorosis (yellowing) of cabbage plants late in the growing season due to root-knot nematode infestation. Plants on left are more severely damaged than those on the right due to varying nematode populations and environmental factors. Credits: Zane Grabau, UF/IFAS

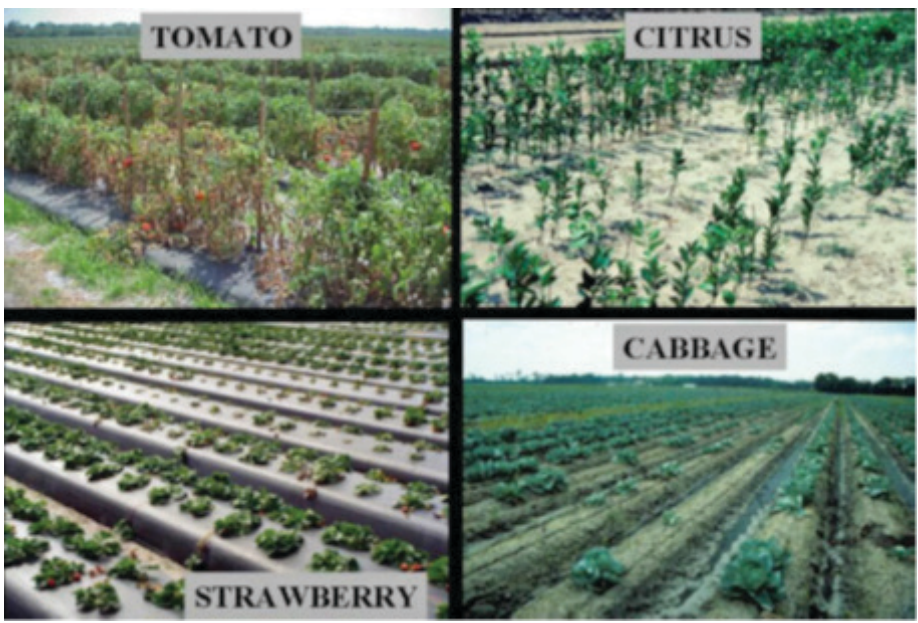

Figure 5. Plant stunting caused by sting (Belonolaimus longicaudatus) or root-knot nematode (Meloidogyne spp.) in various field crops. Note irregular or patchy field distribution of stunted plants rather than throughout the entire field.

Credits: Joe Noling, UF/IFAS

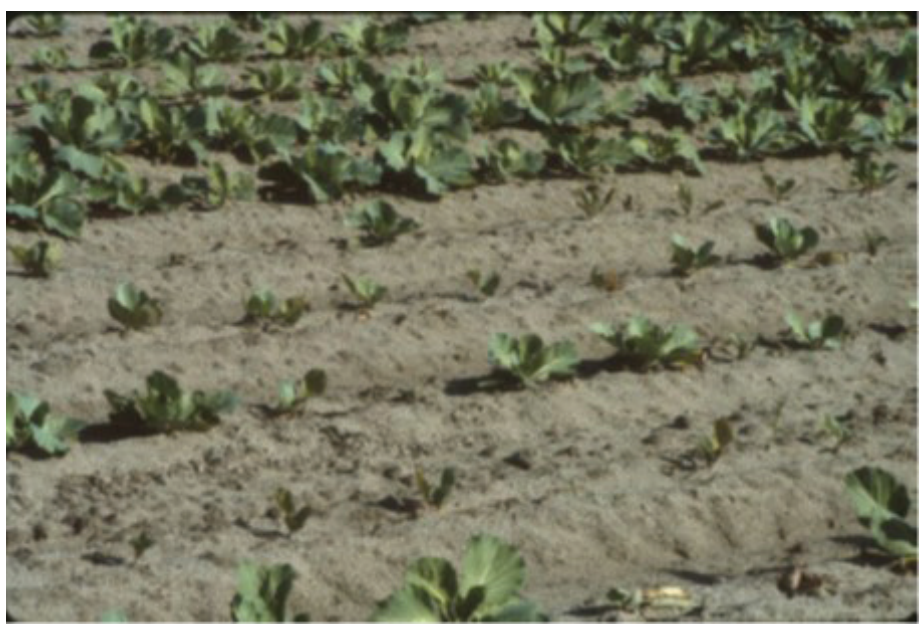

Figure 6. Sting nematode-induced stunting of cabbage and poor stand establishment.

Credits: Joe Noling, UF/IFAS

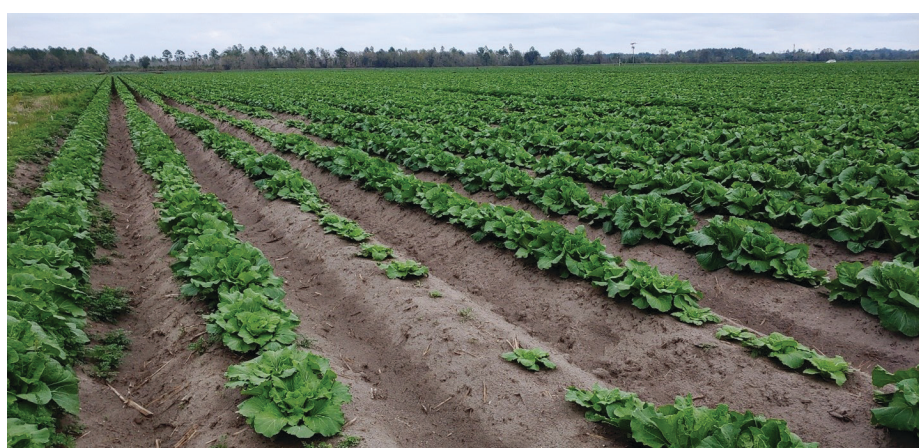

Figure 7. Stunted cabbage and poor stand late in the growing season due to root-knot nematode infestation. Symptoms are patchy with irregular distribution based on nematode populations and environmental factors such as soil moisture.

Credits: Zane Grabau, UF/IFAS

Root symptoms induced by sting or root-knot nematodes are often more specific than aboveground symptoms. Sting nematode can be very injurious, causing infected plants to form a tight mat of short roots that are often swollen at the tips (Figure 8). New root initials are often killed by heavy infestations of the sting nematode, resembling fertilizer salt burn (Figure 9). Root symptoms induced by root-knot nematodes include swollen areas (galls) on the roots of infected plants (Figure 10). Gall size may range from a few spherical swellings to extensive areas of elongated, convoluted, tumorous swellings that result from exposure to multiple and repeated infections when root-knot nematode abundance is substantial. Symptoms of root or tuber galling can provide positive diagnostic confirmation of root-knot nematode presence, infection severity, and potential for crop damage in most cases.

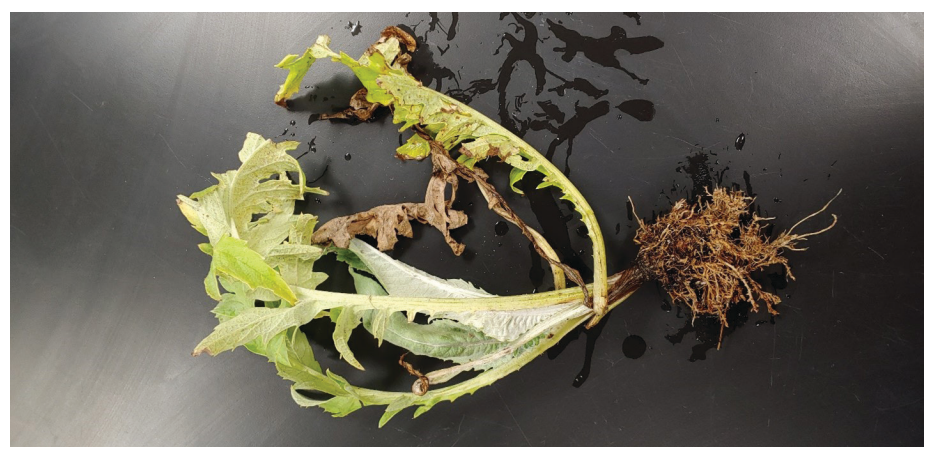

Figure 8. Sting nematode symptoms on artichoke root system. Note stunted, matted, and necrotic (brown, dying tissue) root system as well as lateral root pruning and proliferation, which is illustrated in more detail in Figure 9. Shoot is also severely stunted.

Credits: Zane Grabau, UF/IFAS

The timing and severity of nematode damage symptoms are related to nematode population density, species of plantparasitic nematodes present, crop susceptibility, and prevailing environmental conditions. Sting nematode is very damaging even at low abundance, and symptoms generally appear early in the season. In contrast, cole crops have a 
somewhat greater tolerance for root-knot nematodes, and symptoms tend to appear later in the year. The more severe the nematode pressure (the greater the abundance), the earlier and more severe the symptoms. Under less severe infestation levels, symptom expression may be delayed until later in the crop season after a number of nematode reproductive cycles have been completed on the crop. In this case, aboveground symptoms will not always be readily apparent early within crop development, but with time and reduction in root system size and function, symptoms may become more pronounced and diagnostic. In some cases, damage symptoms may be too subtle to detect even if yield loss is occurring.

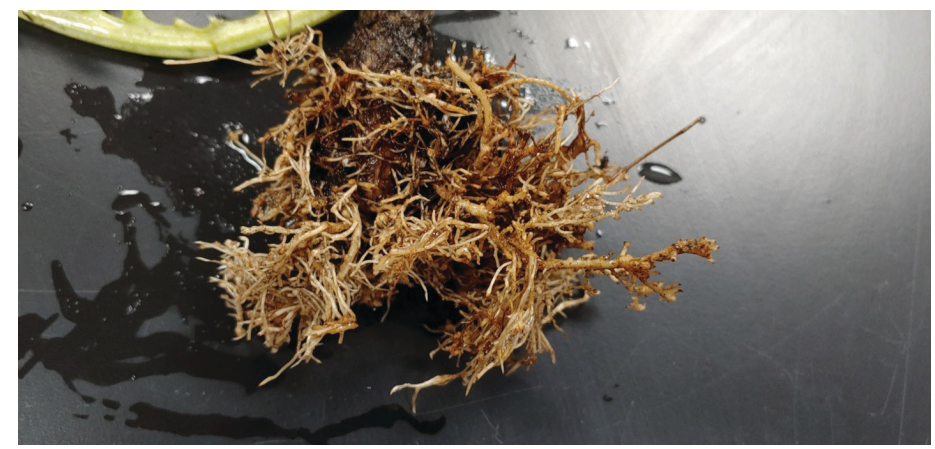

Figure 9. Close-up view of sting nematode damage on artichoke roots. Lateral roots are short with root tips that are swollen and look burned due to severe necrosis (brown, dying tissue). Also note general necrosis of root system.

Credits: Zane Grabau, UF/IFAS

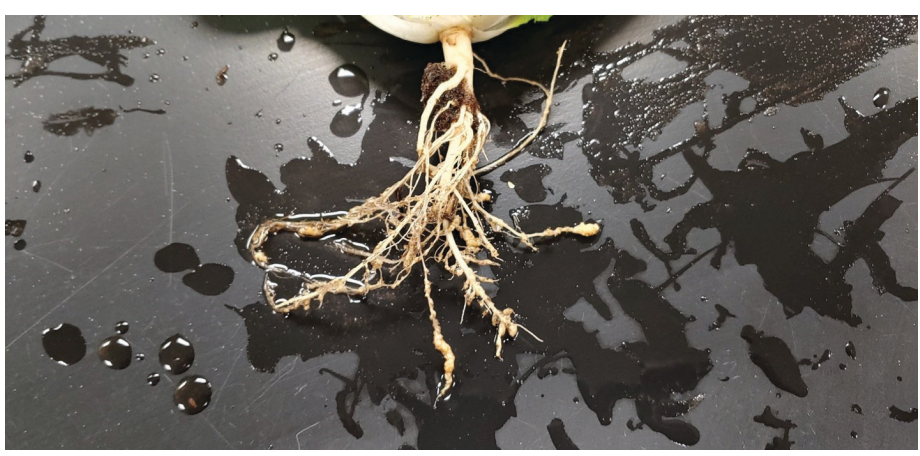

Figure 10. Severe galling (irregularly shaped swellings) of cabbage roots due to root-knot nematode infestation

Credits: Zane Grabau, UF/IFAS

Plant-parasitic nematodes reduce cole crop yield by impairing root function, leading to reduced growth and, consequently, reduced yield. Impaired root function reduces water and nutrient uptake, which impairs plant growth (Figure 11). Damage symptoms and yield loss generally increase as infestation levels of a particular nematode increase. Environmental stress (drought, low fertility, other diseases, etc.) exacerbates damage. Additionally, damage potential varies by nematode. For example, a few sting nematodes can cause substantial yield loss, whereas a few hundred lesion nematodes cause little yield loss. Susceptibility and tolerance to a particular nematode vary by crop. (A crop on which a nematode is able to reproduce and cause damage is said to be susceptible to that nematode; a crop able to maintain yield despite nematode infection and reproduction is said to be tolerant to that nematode.) A summary of the susceptibility of common Florida cole crops to common plant-parasitic nematodes is provided in Table 1, but not all combinations have been tested. Furthermore, for most cole crop and nematode combinations, damage functions (expected yield loss at various nematode population levels) for a given nematode have not been accurately determined. Longer-season crops grown in warmer months tend to be at greater risk for nematode damage because these conditions favor buildup of nematode populations.

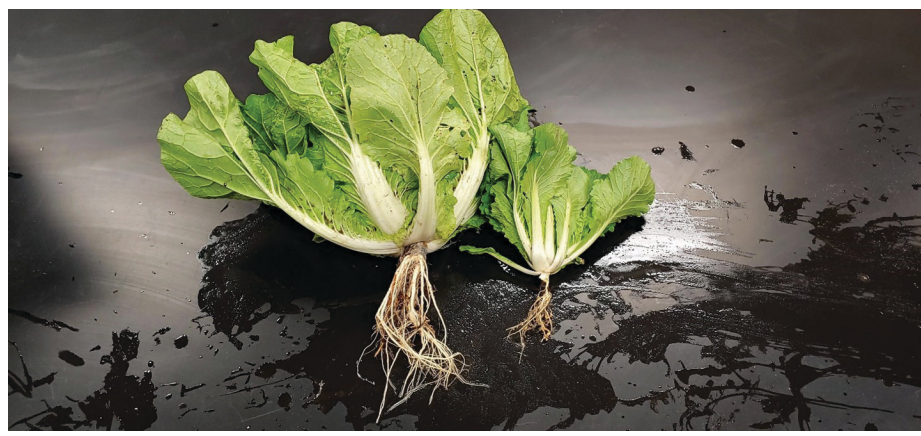

Figure 11. Severe root-knot nematode infestation impairs root function leading to reduced growth (right plant) compared with healthy plant (left plant). The infested plant has a stunted root system with fewer lateral roots and severe galling (irregularly shaped swelling of the root).

Credits: Zane Grabau, UF/IFAS

\section{Field Diagnosis and Sampling}

Soil/tissue sampling and submission to a professional nematode diagnostic lab such as the UF/IFAS Nematode Assay Laboratory is usually required to confirm nematode problems. Nematode sampling is either (1) predictive: determining risk of nematode damage before planting a given crop, or (2) diagnostic: determining if disease symptoms in a crop are caused by nematodes. Predictive samples must be taken before the crop is planted because current nematode management tactics must be deployed at or before planting. Similarly, diagnostic samples are useful for planning management for subsequent crops, but are too late for the current crop. Proper collection and submission of samples using the following steps is key for successful nematode diagnosis.

1. Always include a soil sample when assessing nematodes. Supplementing with root samples, if plants are growing in the field, can also be useful for assessment, but soil is essential. Some nematodes (ectoparasites) can only be detected in soil because they do not fully enter the roots 
and may not be detected in root samples. All nematodes have at least one life stage that can be found in the soil.

2. The best timing for taking predictive samples is just before harvest of the previous crop because this is when nematode abundances are greatest and when this pest is easiest to detect. Take diagnostic samples when symptoms appear. Sample only when soil moisture is appropriate for working the field. Avoid extremely dry or wet soil conditions because it will be difficult to detect nematodes in these samples.

3. Collect soil samples from 10 to 20 field locations using a cylindrical sampling tube, a trowel, or a shovel. Because most species of nematodes are concentrated in the crop rooting zone, samples should be collected to a soil depth of at least 6 to 12 inches. If plants are growing in the field, collect soil samples within a few inches of the plants in order to inspect the rooting zone where nematode abundances are greatest. Because nematode abundances are patchy, collect cores from multiple locations within a field to get a representative sample. Collect root samples in a similar manner.

4. If sampling in fallow fields or in a crop with no obvious nematode symptoms, sample in a regular pattern over an area of no more than 5 acres, emphasizing removal of samples across rather than along rows. If sampling in a symptomatic field, concentrate sampling in areas with diseased-but not dead-plants. (Nematode populations may have already declined in areas with dead plants because their food source is gone.) It can also be helpful to collect a sample from a healthy area of the field for comparison purposes.

5. Once all soil cores for a single sample are collected, the entire sample should be mixed thoroughly but carefully, and a 1 - to 2-pint subsample placed into an appropriately labeled plastic bag. The plastic bag will prevent drying of the sample and help ensure that it is intact when it arrives at the laboratory. Never subject the sample(s) to overheating, freezing, drying, prolonged periods of direct sunlight, or mechanical damage such as tossing bags. If possible, store samples in a cooler in the field and transfer them to a refrigerator at $40^{\circ} \mathrm{F}-60^{\circ} \mathrm{F}$ until submission.

6. Root samples should be handled in a similar manner. If submitting root samples, select 2-5 of the most symptomatic roots (depending on plant size). Submitting root samples can be helpful for diagnosing damage based on symptoms, even if you do not intend to quantify nematodes from roots. If you are unable to mail roots, it is helpful to take pictures of symptomatic roots and submit them by email. Similarly, pictures of foliar symptoms are helpful for assessment.

7. If possible, submit samples the same day as collection by the quickest delivery method feasible. Samples may be exposed to conditions detrimental to nematodes during mailing, so longer delivery periods may reduce nematode recovery. Avoid multiday shipping over the weekend. Wait to submit these samples until early in the week. Store samples at $40^{\circ} \mathrm{F}-60^{\circ} \mathrm{F}$ if you need to wait to submit them.

\section{Be sure to provide accurate and full information on} forms, particularly about crop history, symptoms, and nematode management practices. This information will help inform recommendations.

For each sample submitted, the UF/IFAS Nematode Assay Lab will provide a report of the genera and quantity of plant-parasitic nematodes in each sample, as well as an assessment of damage risk and management recommendations. Contact your local Extension agent or Z. J. Grabau for assistance with nematode sampling or for a field consultation. Assessment of incidence and severity of root symptoms, particularly galling, which is diagnostic for root-knot nematodes, can be a valuable tool for diagnosing the severity and field location of nematode problem, and the UF/IFAS Nematode Assay Lab can assist with this.

\section{Nematode Management}

Nematode management strategies rely on reducing nematode abundances to reduce crop damage or choosing a cultivar that is resistant or tolerant to a particular nematode. The primary nematode management strategies include (1) use of resistant or tolerant cultivars, (2) crop rotation and other cultural practices, (3) nematicide application, and (4) biological control. Not all management practices are equally effective in controlling plant-parasitic nematodes and costs also vary. When possible, multiple management strategies should be integrated as part of a systems approach. The species and abundance of plant-parasitic nematodes in a given field will influence which practices are most effective or necessary, and therefore sampling is an important part of selecting a nematode management strategy. Grower operations (rotation capacity, equipment, and input strategy) also determine what management can be used.

\section{Cultivar and Transplant Selection}

Use of nematode-free transplants is an important consideration for nematode management in cole crops. 
Nematode infestation at the transplant stage is particularly problematic because the earlier plants are infested, the greater the eventual damage. To ensure transplants are free of nematodes, use transplants grown in sterilized potting material or field soil that is properly managed for nematodes, ideally with a fumigant.

Risk of nematode damage can vary by cole crop and cultivar, and these choices are part of nematode management. Most of this variation is due to host status of a particular cole crop and relative tolerance among cultivars. Susceptibility of common cole crops to various nematodes is summarized in Table 1 and can be used as a guide to aid in crop selection. Nematode tolerance of current cole crop cultivars is not well described. Resistant cultivars reduce or eliminate reproduction of a specific nematode, allowing the cultivar to escape damage and reduce nematode abundances for the next crop. There are no known cole crop cultivars with resistance to any nematode genera in Florida, although formal screening has not been done for most crop-nematode combinations.

\section{Crop Rotation}

When possible, crop rotation with unrelated crops is a sound practice for reduction of nematode populations. Rotation with cash crops during the typical growing season or with cover crops not harvested for sale during typically fallow periods are both beneficial. When a crop is planted that is not a host, or is a poor host, of the nematodes in a given field, nematode populations will steadily decline over time. In addition, certain crops produce allelochemicals that may actively reduce nematode populations. Sunn hemp and velvet bean are potential summer cover crops known to produce allelochemicals that can have nematicidal effects. Cole crops themselves also contain potential allelochemicals, but they have been selected to reduce concentrations of these compounds because people find them unpalatable. Even for crops that produce allelochemicals, it is important to consider the host status of the crop because growing a host crop may negate any benefit of allelochemicals for nematode management of the next crop. The amount of time a field needs to be rotated to a nonhost crop to reduce nematode populations below a damaging level will vary based on many factors including initial nematode populations, environmental conditions, and other management practices used. Often, multiple seasons of nonhost crop are needed to reduce nematode populations below a damaging level.

It is not possible to find rotation or cover crops that will reduce populations of all nematode pests of cole crops, so it is important to determine which nematode species are present in a given field. When multiple species are present, it is often useful to design crop rotation to reduce root-knot nematodes, the most difficult nematodes to control with chemicals. Table 1 summarizes the reported host status of some common rotation or cover crops for the major cole crop nematodes in Florida. Note that nematode-crop interactions can vary by cultivar and nematode population, so the management success of a particular crop in a particular field may vary from what is reported in the literature. Grasses, such as corn or sorghum-sudangrass, are excellent hosts of sting and stubby-root nematodes and should be avoided if possible when these nematodes are present. Certain summer cover crops, such as sunn hemp, velvet bean, and hairy indigo, may be useful for sting nematode management. Most cash crops commonly rotated with cole crops are hosts of the three major root-knot nematodes in Florida (southern, peanut, and Javanese root-knot nematodes) except for a few crops (soybean, tomato, and peppers) for which resistant cultivars are available. Several summer cover crops (sunn hemp, sorghum-sudangrass, velvet bean, hairy indigo, and American jointvetch) are reported to be poor hosts of root-knot nematodes and may be useful for management of these nematodes. For more information, see these publications on Florida cover crop production (Wright et al. 2017), Cover Crops for Root-Knot Nematode (Gill and McSorley 2017), and nematode management using sunn hemp (Wang and McSorley 2018a), cowpea (Wang and McSorley 2018b), and sorghum-sudangrass (Dover et al. 2018). For further guidance on potential rotation or cover crops for nematode management, contact your local UF/IFAS Extension agent or Z. J. Grabau.

\section{Other Cultural Practices}

Proper weed management is an important component of nematode management because weeds can serve as hosts for plant-parasitic nematodes and increase or maintain populations during fallow or when a nonhost crop is grown. For example, nutsedge, pigweed, and lambsquarter, among many others, are generally good hosts of root-knot nematodes. Additionally, crops should be terminated by herbicide application or tillage as soon as possible after a crop is harvested to ensure death and desiccation or decomposition of all host plant roots. If crops are left in the field after harvest, nematodes can continue to reproduce on their roots after harvest. Clean fallowing can also reduce nematode populations because it eliminates host plants, but it also carries the risk of soil erosion. Tillage may contribute to reducing nematode abundances because it heats, dries, and mechanically disturbs the soil. Finally, any practices 
that promote plant health, such as proper irrigation, maintenance of soil fertility, and management of other diseases, can increase plant tolerance to nematodes.

\section{Chemical Control}

Most fields in which nematodes have previously damaged cole crops or other crops should be treated with nematicides to improve cole crop production. This is especially true on land that is heavily cropped to cole crops and other crops susceptible to the same nematodes. Selection of a nematicide should be based on the kinds of nematodes and soilborne diseases present in the field, the susceptibility of the specific cole crop grown, field conditions at soil preparation time, and intended market (degree of control needed).

\section{FUMIGANT NEMATICIDES}

Fumigants are pesticides that move through the soil as gases (Table 2). Typically, the best-performing fumigants are the most effective chemical option for nematode management in Florida. Most fumigants are broad-spectrum-they may have activity against nematodes, fungal or bacterial pathogens, and weeds. Current fumigants do not provide consistently excellent control of all of these pests (Table 3), so a combination of chemistries or management strategies is often needed for pest management in vegetable production. Successful fumigation relies on sufficient movement throughout a broad swath of soil, infiltrating pore space where nematodes reside. Because of this, soil conditions and application techniques affect fumigant performance. Many of these conditions are also now specified on fumigant labels as Good Agricultural Practices (GAPs) developed by the EPA to reduce pesticide emissions. Adequate soil moisture (50\%-80\%), high enough soil temperature $\left(60^{\circ} \mathrm{F}\right.$ or greater $)$, and absence of undecomposed plant residue are among soil factors that contribute to effective fumigation. Deep placement of fumigant when applied preplant using a shank/chisel rig, generally 10 inches or greater, is one application technique to optimize fumigant efficacy. (A shank/chisel rig delivers fumigant at the bottom of narrow channels in soil created by the shank/ chisel-often in combination with other tillage equipment, such as a coulter.) Properly sealing soil to prevent premature release of fumigant gases through channels and traces is also critical. This can be done by covering with plastic or disrupting shank traces and compacting soil, depending on the crop system. Most fumigants can be injurious to plants (phytotoxic) if applied too close to planting. Minimize risk of phytoxicity by allowing enough time (two weeks or more depending on product and application rate) between application and planting.

\section{NONFUMIGANT NEMATICIDES}

Non-fumigant nematicides are liquid or granular products that move through the soil in water (Figure 8). Various nonfumigant nematicides are currently registered for use in cole crops and can be applied by various means intended to incorporate the nematicides into rooting zone of the soil (Table 4). Non-fumigant nematicides generally provide a narrower spectrum of activity than fumigants, primarily targeting nematodes, although certain products also have efficacy against insects (Majestene and MoCap 15G) or fungal pathogens (Velum Prime). Efficacy of nonfumigants varies by product, but nonfumigants are generally less effective than fumigants for control of most nematodes in vegetable crops (Table 5). Chemical nonfumigants work by coming into contact with nematodes in the soil, or, if the product has systemic activity, by being taken up by the plant (Table 5). Therefore, the ability of a product to dissolve and move in water (solubility) and the length of time it takes for the compound to break (persistence) greatly influence the efficacy of nonfumigants. Mobile nonfumigants (MoCap and Nimitz) are likely to come in contact with nematodes in the soil more quickly than poorly mobile nonfumigants. Mobile products also move out of the rooting zone more quickly, particularly with excess rainfall, which could reduce nematode exposure and increase risk of leaching. A highly persistent nematicide (Velum Prime) will stay in the soil longer, increasing exposure to nematodes. Human toxicity of these products, and thus required handler precautions, also vary by nematicide. Some nonfumigant nematicides can be phytotoxic. In particular, Nimitz must be applied 30 days or more before transplanting to avoid phytotoxicity, and MoCap 15G should not be placed in contact with plant seeds.

In addition to product characteristics, application methods and soil conditions will greatly influence nematicide efficacy. Always refer to the latest label instructions for proper application procedures. In general, nonfumigants are most effective when they are uniformly applied to soil and targeted toward the future rooting zone of the plant, where they will contact nematodes or be absorbed by the plant. Non-fumigant materials work best in moist soils, generally above $12 \%$ to $15 \%$ moisture. Proper tillage or irrigation is also critical, particularly for relatively immobile products, in order to thoroughly mix nonfumigants in the soil where cole crops will be planted.

\section{Biological Control}

Biological control uses living organisms to manage pests. Biological control organisms used against nematodes either produce chemicals detrimental to nematodes or directly 
parasitize nematodes. One method of biological control is an inundative approach where biological control organisms are introduced to the field, generally as a commercial product. Two products that could be considered biological control methods, Majestene and MeloCon WG, are listed in Tables 4 and 5. Majestene is made of dead Burkholderia bacteria and the fermentation product in which the bacteria was cultured. Because Majestene contains no live organisms, in principle, it is similar to chemical nonfumigant nematicides in that it relies on the nematicidal material coming in contact with the nematodes. Melocon WG contains live Purpureocillium lilacinum fungi, so its efficacy is dependent not only on proper distribution in the soil, but also conditions being favorable for the fungi to establish in the environment and to infect nematodes.

A second approach to biological control is making use of biological control organisms that are native to soil. Many biological control organisms are known to reside in soil, and there are field locations suppressive to nematodes (nematode populations maintained lower than expected despite susceptible crop). Suppression is often related to crop monoculture without broad-spectrum fumigants or other pesticides that affect microbe communities. Crop monoculture is not recommended as a method of biological control because there is no guarantee suppression will take hold; it requires sustaining a period of intense nematode pressure; and there are other agronomic penalties of crop monoculture. Reduced tillage and increased organic matter input, such as thorough cover cropping, may induce biological control, but currently there is no reliable formula to do this for Florida crops.

\section{References}

Anwar, S. A., and M. V. McKenry. 2010. "Incidence and Reproduction of Meloidogyne incognita on Vegetable Crop Genotypes." Pakistan Journal of Zoology 42:135-141.

Carneiro, R. M. D. G., O. Randig, M. R. A. Almeida, and A. D. Campos. 2000. "Resistance of Vegetable Crops to Meloidogyne spp.: Suggestion for a Crop Rotation System." Nematologia Brasileira 24: 49-54.

Crow, W. T. 2013. "Effects of a Commercial Formulation of Paecilomyces lilacinus Strain 251 on Overseeded Bermudagrass Infested with Belonolaimus longicaudatus." Journal of Nematology 45: 223.

Crow, W. T. 2017. Stubby-Root Nematode, Nanidorus minor (colbran) Siddiqi (syn. Paratrichodorus minor, P. christiei, Trichodorus minor, T. christiei) (Nematoda: Adenophorea:
Triplonchida: Diphtherophorina: Trichodoridea: Trichodoridae). ENY-339. Gainesville: University of Florida Institute of Food and Agricultural Sciences. https://edis.ifas.ufl.edu/ in616

Crow, W. T. 2018. Belonolaimus longicaudatus Rau (Nematoda: Secernentea: Tylenchida: Tylenchina: Belonolaimidae: Belonolaiminae). ENY-239. Gainesville: University of Florida Institute of Food and Agricultural Sciences. https:// edis.ifas.ufl.edu/in395

Crow, W. T., and B. S. Brammer. 2018. Awl nematodes, Dolichodorus spp. Cobb, 1914 (Nematoda: Secernentea: Tylenchida: Tylenchina: Dolichodoridae: Dolichodorinae). ENY-241. Gainesville: University of Florida Institute of Food and Agricultural Sciences. https://edis.ifas.ufl.edu/ in397

Crow, W. T., D. P. Weingartner, D. W. Dickson, and R. McSorley. 2001. "Effect of Sorghum-Sudangrass and Velvetbean Cover Crops on Plant-Parasitic Nematodes Associated with Potato Production in Florida." Journal of Nematology 33: 285-288.

Culbreath, A. K., R. Rodriguez-Kabana, and G. MorganJones. 1986. "Chitin and Paecilomyces lilacinus for Control of Meloidogyne arenaria.” Nematropica 16: 153-166.

Desaeger, J. A., and T. T. Watson. 2019. "Evaluation of New Chemical and Biological Nematicides for Managing Meloidogyne javanica in Tomato Production and Associated Double Crops in Florida." Pest Management Science 75: 3363-3370. https://doi.org/10.1002/ps.5481

Di Vito, M., N. Vovlas, and P. Castillo. 2004. "HostParasite Relationships of Meloidogyne incognita on Spinach." Plant Pathology 53: 508-514. https://doi. org/10.1111/j.1365-3059.2004.01053.x

Dias-Arieira, C. R., T. P. da Cunha, F. M. Chiamolera, H. H. Puerari, F. Biela, and S. d. M. Santana. 2012. "Reaction of Vegetables and Aromatic Plants to Meloidogyne javanica and M. incognita." Horticultura Brasileira 30: 322-326. https://doi.org/10.1590/S0102-05362012000200023

Dover, K., K. H. Wang, and R. McSorley. 2018. Nematode Management Using Sorghum and Its Relatives. ENY-716. Gainesville: University of Florida Institute of Food and Agricultural Sciences. http://edis.ifas.ufl.edu/in531

Gill, H. K., and R. McSorley. 2017. Cover Crops for Managing Root-Knot Nematodes. ENY-063. Gainesville: University 
of Florida Institute of Food and Agricultural Sciences. http://edis.ifas.ufl.edu/in892

Grabau, Z. J., and C. Liu. 2019a. "Fumigant and Nonfumigant Nematicides for Root-Knot Nematode Management in Florida Tomato, 2018." Plant Disease Management Reports 13: N004. http://www.plantmanagementnetwork.org/pub/ trial/PDMR/volume13/

Grabau, Z. J., and C. Liu. 2019b. "Impact of Nematicide Application on Root-Knot Nematode Management in Florida Spring Watermelon." Plant Disease Management Reports 13: N006. http://www.plantmanagementnetwork.org/pub/trial/ PDMR/volume13/

Grabau, Z. J., J. W. Noling, and P. A. Navia Gine. 2019. "Fluensulfone and 1,3-Dichloroprene for Plant-Parasitic Nematode Management in Potato Production." Journal of Nematology 51: UNSP e2019-38. https://doi.org/10.21307/ jofnem-2019-038

Hewlett, T. E., D. W. Dickson, D. J. Mitchell, and M. E. Kannwischer-Mitchell. 1988. "Evaluation of Paecilomyces lilacinus as a Biocontrol Agent of Meloidogyne javanica on Tobacco." Journal of Nematology 20: 578.

Khan, A. A., and M. W. Khan. 1991. "Penetration and Development of Meloidogyne incognita Race 1 and Meloidogyne javanica in Susceptible and Resistant Vegetables. Nematropica 21: 71-77.

Khan, T. A., M. S. Ashraf, and R. A. Dar. 2010. "Pathogenicity and Life Cycle of Meloidogyne javanica on Broccoli." Archives of Phytopathology and Plant Protection 43: 602-608. https://doi.org/10.1080/03235400801972392

Kim, D., Y. Ryu, C. Huh, and Y. Lee. 2013. "Resistance of Newly Introduced Vegetables to Meloidogyne arenaria and M. incognita in Korea." Research in Plant Disease 19: 294-299. https://doi.org/10.5423/RPD.2013.19.4.294

Kinloch, R. A., and L. S. Dunavin. 1993. "Summer Cropping Effects on the Abundance of Meloidogyne arenaria Race 2 and Subsequent Soybean Yield. Journal of Nematology 25: 806-808.

Kurppa, A., A. T. Jones, B. D. Harrison, and K. W. Bailiss. 1981. "Properties of Spinach Yellow Mottle, a Distinctive Strain of Tobacco Rattle Virus." Annals of Applied Biology 98: 243-254.
Liu, C., and Z. J. Grabau. 2019. "Nematode Management at Different Nematicide Application Time in North Florida Tomato, 2018." Plant Disease Management Reports 13: N010. http://www.plantmanagementnetwork.org/pub/trial/ PDMR/volume13/

McSorley, R. 1994. "Changes in Population-Densities of Meloidogyne spp. and Paratrichodorus minor on Winter Rye Cover Crops." Nematropica 24: 151-160.

McSorley, R., and D. W. Dickson. 1995. "Effect of Tropical Rotation Crops on Meloidogyne incognita and Other PlantParasitic Nematodes." Journal of Nematology 27: 535-543.

McSorley, R., D. W. Dickson, and J. A. DeBrito. 1994. "Host Status of Selected Tropical Rotation Crops to 4 Populations of Root-Knot Nematodes." Nematropica 24: 45-53.

McSorley, R., and J. J. Frederick. 1995. "Responses of Some Common Cruciferae to Root-Knot Nematodes." Journal of Nematology 27: 550.

McSorley, R., and R. N. Gallaher. 1993. "Effect of CropRotation and Tillage on Nematode Densities in Tropical Corn." Journal of Nematology 25: 814-819.

Perez, E. E., D. P. Weingartner, and R. McSorley. 2000a. "Correlation between Paratrichodorus minor Population Levels and Corky Ringspot Symptoms on Potato." Nematropica 30: 247-251.

Perez, E. E., D. P. Weingartner, and R. McSorley. 2000 b. "Niche Distribution of Paratrichodorus minor and Belonolaimus longicaudatus Following Fumigation on Potato and Cabbage." Journal of Nematology 32: 343-348.

Rhoades, H. L. 1970. "Occurrence of the Sugarbeet Nematode, Heterodera schachtii, in Florida." Plant Disease Reporter 54: 635.

Rhoades, H. L. 1971. "Chemical Control of Sting Nematode, Belonolaimus longicaudatus, on Direct-Seeded Cabbage." Plant Disease Reporter 55: 412-414.

Rhoades, H. L. 1986. "Effects of Fumigant and Nonfumigant Nematicides on Belonolaimus longicaudatus and Hoplolaimus galeatus Populations and Subsequent Yield of Cabbage." Plant Disease 70: 581-582.

Rhoades, H. L. 1987. "Effects of Fumigant and Nonfumigant Nematicides on Nematode Populations and Yields of Broccoli and Squash in Florida." Nematropica 17: 193-198. 
Rodriguez-Kabana, R., J. Pinochet, D. G. Robertson, and L. Wells. 1992. "Crop-Rotation Studies with Velvetbean (Mucuna deeringiana) for the Management of Meloidogyne spp." Journal of Nematology 24: 662-668.

Rodriguez-Kabana, R., D. B. Weaver, D. G. Robertson, R. W. Young, and E. L. Carden. 1990. "Rotations of Soybean with 2 Tropical Legumes for the Management of Nematode Problems." Nematropica 20: 101-110.

Wang, K. H., R. J. McGovern, R. McSorley, and R. N. Gallaher. 2004. "Cowpea Cover Crop and Solarization for Managing Root-Knot and Other Plant-Parasitic Nematodes in Herb and Vegetable Crops." Soil and Crop Science Society of Florida Proceedings 63: 99-104.

Wang, K. H., and R. McSorley. 2018a. Management of Nematodes and Soil Fertility with Sunn Hemp Cover Crop. ENY-717. Gainesville: University of Florida Institute of Food and Agricultural Sciences. http://edis.ifas.ufl.edu/ ng043

Wang, K. H., and R. McSorley. 2018b. Management of Nematodes with Cowpea Cover Crops. ENY-712. Gainesville: University of Florida Institute of Food and Agricultural Sciences. http://edis.ifas.ufl.edu/in516

Watson, T. T., and J. A. Desaeger. 2019. "Evaluation of Nonfumigant Chemical and Biological Nematicides for Strawberry Production in Florida." Crop Protection 117: 100-107. https://doi.org/10.1016/j.cropro.2018.11.019

Weingartner, D. P., R. McSorley, R. and R. W. Goth. 1993. "Management Strategies in Potato for Nematodes and Soil-Borne Diseases in Subtropical Florida." Nematropica 23: $233-245$.

Wright, D. L., C. Mackowiak, and A. Blount. 2017. Cover Crops. SS-AGR-66. Gainesville: University of Florida Institute of Food and Agricultural Sciences. http://edis.ifas. ufl.edu/aa217 
Table 1. Host status of selected cash and summer cover crops for common plant-parasitic nematodes in Florida cole crop production. ${ }^{1}$

\begin{tabular}{|c|c|c|c|c|c|}
\hline & $\begin{array}{l}\text { Southern } \\
\text { Root-Knot } \\
\text { Nematode }\end{array}$ & $\begin{array}{l}\text { Peanut } \\
\text { Root-Knot } \\
\text { Nematode }\end{array}$ & $\begin{array}{l}\text { Javanese } \\
\text { Root-Knot } \\
\text { Nematode }\end{array}$ & $\begin{array}{l}\text { Stubby-Root } \\
\text { Nematode }\end{array}$ & Sting Nematode \\
\hline \multicolumn{6}{|l|}{ Cole Crops } \\
\hline Broccoli & Varies & Host & Host & Unknown & Unknown \\
\hline Cabbage & Host & Host & Varies & Host & Host \\
\hline $\begin{array}{l}\text { Cauliflower (Brassica } \\
\text { oleracea) }\end{array}$ & Varies & Host & Varies & Unknown & Host \\
\hline $\begin{array}{l}\text { Napa cabbage (Brassica } \\
\text { rapa ssp. pekinensis) }\end{array}$ & Host & Host & Host & Unknown & Unknown \\
\hline Spinach (Spinacia oleracea) & Host & Host & Host & Host & Unknown \\
\hline \multicolumn{6}{|l|}{ Other Cash Crops } \\
\hline Corn & Host & Varies & Host & Host & Host \\
\hline Potato & Host & Host & Host & Host & Host \\
\hline Soybean & Host $^{2}$ & Host & Host & Host & Host \\
\hline Sweet potato & Host $^{2}$ & Host & Host & Unknown & Unknown \\
\hline Tomato & Host $^{2}$ & Host $^{2}$ & Host $^{2}$ & Host & Host \\
\hline Watermelon & Host & Host & Host & Unknown & Poor/nonhost \\
\hline \multicolumn{6}{|l|}{ Cover Crops } \\
\hline Sorghum-sudangrass & Poor/nonhost & Poor/nonhost & Poor/nonhost & Host & Host \\
\hline Sunn hemp & Poor/nonhost & Poor/nonhost & Poor/nonhost & Unknown & Poor/nonhost \\
\hline Cowpea & Host $^{2}$ & Host $^{2}$ & Host $^{2}$ & Varies & Host \\
\hline Velvet bean & Poor/nonhost & Poor/nonhost & Poor/nonhost & Host & Poor/nonhost \\
\hline Hairy indigo & Poor/nonhost & Poor/nonhost & Poor/nonhost & Unknown & Poor/nonhost \\
\hline Jointvetch & Poor/nonhost & Poor/nonhost & Poor/nonhost & Host & Unknown \\
\hline \multicolumn{6}{|c|}{$\begin{array}{l}\text { 'Information is based on observations and literature at the time of publication (Rodriguez-Kabana et al. 1990; Khan, A. A. ,and Khan 1991; } \\
\text { Rodriguez-Kabana et al. 1992; Weingartner et al. 1993; McSorley and Gallaher 1993; Kinloch and Dunavin 1993; McSorley et al. 1994; McSorley } \\
\text { 1994; McSorley and Dickson 1995; McSorley and Frederick 1995; Carneiro et al. 2000; Perez et al. 2000a; Crow et al. 2001; Wang et al. 2004; Di } \\
\text { Vito et al. 2004; Anwar and McKenry 2010; Khan et al. 2010; Dias-Arieira et al. 2012; Kim et al. 2013). } \\
\text { Relationships may differ for specific nematode populations and crop cultivars. Poor = poor or nonhost; Good = good host; Unknown = host } \\
\text { status is unknown or has not been formally reported; Varies = susceptibility varies by cultivar or report (may suggest an intermediate level of } \\
\text { susceptibility). } \\
{ }^{2} \text { Resistant cultivars are available. Most cultivars are good hosts. } \\
{ }^{3} \text { Host range of southern and peanut root-knot nematodes and sting nematode varies by population. }\end{array}$} \\
\hline
\end{tabular}


Table 2. Fumigant nematicides for cole crops in Florida.

\begin{tabular}{|c|c|c|c|}
\hline \multirow[b]{2}{*}{ Nematicide $^{2}$} & \multicolumn{2}{|c|}{ Broadcast Application Rates ${ }^{1}$} & \multirow[b]{2}{*}{ In-the-Row Applications } \\
\hline & Gallons per acre & $\begin{array}{l}\text { fl oz/1000 ft/ chisel } \\
\text { spaced } 12 \text { in apart }\end{array}$ & \\
\hline Telone $\|^{3}$ & 9 to 12 & 26 to 35 & $\begin{array}{l}\text { May be concentrated in row. Do not exceed broadcast } \\
\text { rate. }\end{array}$ \\
\hline Telone C- $17^{3}$ & 10.8 to 17.1 & 31.8 to 50.2 & $\begin{array}{l}\text { May be concentrated in row. Do not exceed broadcast } \\
\text { rate. }\end{array}$ \\
\hline Telone C-35 & 13 to 20.5 & 38.2 to 60.2 & $\begin{array}{l}\text { May be concentrated in row. Do not exceed broadcast } \\
\text { rate. }\end{array}$ \\
\hline Pic-Clor 60 & 19 to 31.5 & 57 to 90 & $\begin{array}{l}\text { May be concentrated in row. Do not exceed broadcast } \\
\text { rate. }\end{array}$ \\
\hline Chloropicrin 99\% & 150 to $350 \mathrm{lb}$ & - & $\begin{array}{l}\text { May be concentrated in row. Do not exceed broadcast } \\
\text { rate. }\end{array}$ \\
\hline Vapam HL & 75 & - & $\begin{array}{l}\text { Must proportionally reduce rates and modify flow for } \\
\text { drip or in-row chisel application. See label. }\end{array}$ \\
\hline KPam HL & 60 & - & $\begin{array}{l}\text { Must proportionally reduce rates and modify flow for } \\
\text { drip or in-row chisel application. See label. }\end{array}$ \\
\hline Dominus & 40 & - & $\begin{array}{l}\text { Must proportionally reduce rates and modify flow for } \\
\text { drip or in-row chisel application. See label. }\end{array}$ \\
\hline \multicolumn{4}{|c|}{$\begin{array}{l}{ }^{1} \text { Rates provided only for mineral soils. Higher rates may be allowed for heavier-textured (loam, silt, clay) or highly organic soils. At the time of } \\
\text { publication, rates are believed to be correct for products named and similar products of other brand names. However, the grower has the final } \\
\text { responsibility to see that each product is used legally. Read the label of the product to be sure that you are using it properly. } \\
{ }^{2} \text { All of the fumigants mentioned are for retail sale and use only by state-certified applicators or persons under their direct supervision. New } \\
\text { supplemental labeling for the Telone products must be in the hands of the user at the time of application. } \\
{ }^{3} \text { Higher application rates are allowed in the presence of cyst-forming nematodes. }\end{array}$} \\
\hline
\end{tabular}

Table 3. Generalized summary of maximum use rate and relative effectiveness of various soil fumigant alternatives to methyl bromide for nematode, soilborne disease, and weed control in Florida.

\begin{tabular}{|c|c|c|c|c|}
\hline \multirow[t]{2}{*}{ Fumigant Trade Name ${ }^{1}$} & \multirow[t]{2}{*}{ Active Ingredient } & \multicolumn{3}{|c|}{ Relative Pesticidal Activity } \\
\hline & & Nematode & Disease & Weed \\
\hline Chloropicrin & Chloropicrin & None to poor & Excellent & Poor \\
\hline Vapam HL & Metam-sodium & Poor to good & Poor to good & Poor to good \\
\hline Telone II & 1,3-Dichloropropene & Good to excellent & None to poor & Poor \\
\hline Telone C17 & 1,3-Dichloropropene + chloropicrin & Good to excellent & Good & Poor \\
\hline Telone C35 & 1,3-Dichloropropene + chloropicrin & Good to excellent & Good to excellent & Poor to fair \\
\hline Pic-Clor 60 & 1,3-Dichloropropene + chloropicrin & Good to excellent & Good to excellent & Poor to fair \\
\hline KPam HL & Metam potassium & Poor to good & Poor to good & Poor to good \\
\hline Dominus & Allyl isothiocyanate & Poor to good & Poor to good & Poor to good \\
\hline
\end{tabular}


Table 4. Nonfumigant products for cole crops in Florida.

\begin{tabular}{|c|c|c|c|}
\hline $\begin{array}{c}\text { Nematicide } \\
\text { (Active Ingredient) }^{1}\end{array}$ & Labeled Rate $^{2}$ & Application Timing & Application Methods \\
\hline $\begin{array}{l}\text { Mocap 15G } \\
\text { (ethoprop) }^{3}\end{array}$ & $\begin{array}{l}34 \mathrm{lb} / a c r e \text { if broadcast; } \\
0.9 \mathrm{lb} / 1000 \text { row-foot if banded }\end{array}$ & $\begin{array}{l}\text { 1. Broadcast }<1 \text { week } \\
\text { preplant } \\
\text { or } \\
\text { 2. Banded at planting }\end{array}$ & $\begin{array}{l}\text { 1. Broadcast spread granules and till to } 2-4 \text { inches } \\
\text { deep. } \\
\text { 2. In } 15 \text {-inch band on row. Mix to } 2-4 \text { inches } \\
\text { immediately after application. Avoid contact with } \\
\text { seed. }{ }^{3} \text { Do not apply in-furrow }\end{array}$ \\
\hline $\begin{array}{l}\text { Majestene (dead } \\
\text { Burkholderia bacteria) }\end{array}$ & $\begin{array}{l}\text { 4-8 quarts/acre. Multiple } \\
\text { applications may be made. }\end{array}$ & n & $\begin{array}{l}\text { Shank, broadcast spray, banded/in-furrow spray, } \\
\text { drench, or chemigation depending on timing. See } \\
\text { label for details. }\end{array}$ \\
\hline $\begin{array}{l}\text { Melocon WG (live } \\
\text { Paecilomyces lilacinus } \\
\text { fungi) }^{4}\end{array}$ & $\begin{array}{l}\text { 1. To field soil: } 2-4 \mathrm{lb} / a c r e \\
\text { 2. To transplants in media: } \\
0.5 \mathrm{lb} / \text { acre. Multiple } \\
\text { applications can be made. }\end{array}$ & $\begin{array}{l}\text { 1. Before planting (to field } \\
\text { or transplants) and } \\
\text { 2. At or after planting at } \\
4-6 \text { week intervals }\end{array}$ & $\begin{array}{l}\text { Shank, broadcast spray, banded/in-furrow spray, } \\
\text { drench, or chemigation depending on timing. See } \\
\text { label for details. }\end{array}$ \\
\hline Nimi & $\begin{array}{l}3.5-7 \text { pt/acre (banded } \\
\text { applications not to be } \\
\text { concentrated in row) }\end{array}$ & $\begin{array}{l}30 \text { days or more before } \\
\text { transplanting }\end{array}$ & $\begin{array}{l}\text { 1. Broadcast or banded spray. Incorporate by tillage } \\
\text { to } 6-8 \text { inches and irrigate ( } 20 \text { gallons/acre) } \\
\text { 2. 3-5 days after application. } \\
\text { Drip or overhead irrigation. }\end{array}$ \\
\hline Velum Prim & $\begin{array}{l}6.5 \text { to } 6.84 \text { oz/acre per } \\
\text { application. } \\
13.7 \text { oz/acre per year. }\end{array}$ & $\begin{array}{l}\text { At planting or preplant } \\
\text { recommended. May be } \\
\text { applied anytime. }\end{array}$ & $\begin{array}{l}\text { Chemigation through drip or similar irrigation } \\
\text { system. } 5 \text { day minimum interval between soil } \\
\text { applications }\end{array}$ \\
\hline \multicolumn{4}{|c|}{$\begin{array}{l}{ }^{1} \text { Provided as guidelines only. Information is subject to changing product registration and labeling. Always read and follow label instructions. } \\
\text { The mention of a product or trade name does not imply endorsement to the exclusion of other products. All of the nematicides mentioned are } \\
\text { restricted-use pesticides for use only by state-certified applicators or persons under their direct supervision. } \\
{ }^{2} \text { Do not exceed greatest listed label rate. Only } 1 \text { application per growing season is allowed unless noted otherwise. } \\
{ }^{3} \text { MoCap } 15 G \text { is labelled for cabbage only, not other cole crops. Contact with seed is a risk of phytoxicity. Phytoxicity risk is less with transplants, } \\
\text { but be aware of handler risks listed on label if transplanted by hand. } \\
{ }^{4} \text { Majestene and Melocon WG are OMRI-listed organic nematicides. } \\
{ }^{5} \text { Velum Prime is considered a FRAC group } 7 \text { fungicide. Rotate chemistries. }\end{array}$} \\
\hline
\end{tabular}

Table 5. Characteristics of nonfumigant products in Florida cole crops.

\begin{tabular}{|l|l|l|l|l|l|l|}
\hline Active Ingredient & $\begin{array}{l}\text { Trade } \\
\text { Name(s) }\end{array}$ & $\begin{array}{l}\text { Handler } \\
\text { Toxicity } \\
\text { Category }\end{array}$ & $\begin{array}{l}\text { Soil Movement } \\
\text { (Water Solubility) }\end{array}$ & $\begin{array}{l}\text { Persistence in } \\
\text { Soil (Half-Life) }\end{array}$ & $\begin{array}{l}\text { Systemic in } \\
\text { Plant? }\end{array}$ & $\begin{array}{l}\text { Relative Efficacy against } \\
\text { Nematodes }\end{array}$ \\
\hline Ethoprop & Mocap 15G & Danger & $\begin{array}{l}\text { High } \\
(843 \mathrm{ppm})\end{array}$ & $\begin{array}{l}\text { Short } \\
\text { (3-56 days) }\end{array}$ & No & Fair to good \\
\hline Live Paecilomyces fungi & MeloCon WG & Caution & N/A & N/A & No & Poor to Fair \\
\hline $\begin{array}{l}\text { Dead Burkholderia } \\
\text { bacteria }\end{array}$ & Majestene & Caution & N/A & No & Poor to Fair \\
\hline Fluensulfone & Nimitz & Caution & $\begin{array}{l}\text { Medium } \\
(545 \mathrm{ppm})\end{array}$ & $\begin{array}{l}\text { Short } \\
\text { (7-17 days) }\end{array}$ & No & Fair to Excellent \\
\hline Fluopyram & Velum Prime & Warning & $\begin{array}{l}\text { Low } \\
(10 \mathrm{ppm})\end{array}$ & $\begin{array}{l}\text { Long, limited } \\
\text { (162-746 days) }\end{array}$ & Fair to Good \\
\hline
\end{tabular}

"EPA-designated terms on product labels to alert handlers to toxicity hazards. "Danger" is the greatest hazard level, followed by "Warning" and "Caution."

${ }^{2}$ Efficacy scale is none to excellent. Efficacy may vary by situation and should be used as a guide only. Most products have not been tested side by side in cabbage trials. Rating is based on published and unpublished Florida research trials in both cole crops and other vegetables (Rhoades 1971; Rhoades 1986; Culbreath et al. 1986; Rhoades 1987; Hewlett et al. 1988; Crow 2013; Watson and Desaeger 2019; Grabau et al. 2019; Liu and Grabau 2019; Desaeger and Watson 2019; Grabau and Liu 2019a; Grabau and Liu 2019b). 